\title{
PRAGMATICS ANALYSIS OF MAXIM FLOUTING DONE BY THE MAIN CHARACTERS IN KUNGFU PANDA MOVIE BY JONATHAN AIBEL \& GLENN BERGER
}

\author{
Triza Hamani, YulanPuluhulawa \\ English Literature - Faculty of Science and Culture \\ University of Muhammadiyah Gorontalo
}

\begin{abstract}
Maxims are the rules to know whether the speaker can be cooperative or not while he contributes the information in conversation. By flouting maxims, the participants of the conversation seem to be uncooperative but actually they do. The participants themselves have certain intentions of flouting the maxims. There are some intended meanings and certain purposes which are conveyed by the speaker behind the utterance where maxim flouting occurs. Hence, by flouting the maxims, the participants are not said to beuncooperative in a conversation. It is because maxim flouting is a way to make the hearer look for the real meaning beyond what is said implicitly by the speaker. This research only focus in analyzing maxim flouting that occurs in the Kungfu Panda Movie. This research uses the Grice's Cooperative Principle and Cutting's theory they are maxim quantity, maxim quality, maxim relation and maxim of manner that flouting by the main character in Kungfu Panda Movie Script. Based on the data analysis , it has been discovered that all the main characters all flouting all the types of maxims. The maxim of quantity flouting becomes the main type of maxim flouting which is performed by the main characters. They have tendency to flout this maxim to make the information given to the listener clearer. It is done by giving too little information rather than giving much one. Meanwhile, maxim of quality and maxim of manner flouting rarely occurs in the movie because the characters are assertive kind of persons. They avoid giving unclear information which leads the understanding of the hearer.
\end{abstract}

Keywords: Maxim flouting, types, strategies, Kungfu Panda movie

\section{INTRODUCTION}

Language has an important role in human social interaction as a main tool of communication. The language used may indicate the intention of someone through communicating a message.A speaker will produce some messages from language that encodes the message as its meaning; the message will be identified and composed by hearer. The communication may be successfully delivered when the hearer decodes the same message that the speaker encodes. It means the hearer has to recognize appropriately the speaker's message. The phenomena existing in the conversation may be elaborated deeply in pragmatics; a term that 
comprehends why the speaker uses the language in particular ways and what the meaning actually beyond the utterance. Pragmatics plays an important role in studying language as a tool of human interaction, i.e the interaction between the speaker and the hearer.To understand 'interactional' meanings expressed in speech and we must have appropriate analytical devices to clarify such meanings (Wierzbicka, 1991: 15).

McManis (1988: 197) stated, we commonly receive inference from what speaker says according to the assumption that he is obeying the Cooperative Principles. This system of inference drawing is a kind of side effect of the maxims; maxims whose primary reason for being is regulate conversation. It means that maxims can be the rules to know whether the speaker can be cooperative or not while he contributes the information in conversation.

\section{Cooperative Principle}

The message in a communication will be successfully delivered by speaker to hearer if they can build cooperation one and another. Even less, the speaker often means more than what he/she literally says and it is not easy to be comprehended by hearer. Grice argued some kinds of cooperative principles must be assumed to be in operation. Thus Grice in Brown and Yule (1983: 32) stated the cooperative principles that have to be conducted appropriately, "Make your conversational contribution such as is required, at the stage at which it occurs, by the accepted purpose or direction of the talk exchange in which you are engaged."

Grice specifically evolves the principle into four sub-principles called maxims. These maxims determine what participant have to do to converse in a maximally efficient, rational, and cooperative way (Levinson, 1983:102). Grice in Black (2006:23) mentions that the maxims are maxim of quantity, maxim of quality, maxim of relation and maxim of manner.

Basically, there are two possible things that people can do with maxim: observing maxim and not observing maxim. Observing maxim means that you are follow the rules of maxim while not observing means that you are break or 
against the rules of maxim. Hence, the focus of this research is not observing maxim. Non-Observance of Maxims

Sometimes, the participants of the conversation seem do not adhere to the four sub-principles. It means that the participants fail to observe the maxims. The failure of observing maxims is done by breaking the rules of them whether deliberately or accidentally and it is called non-observance maxims.

There are four ways of naming some cases related to the failure to observe the maxims. They are opting out, violating, infringing, and flouting.

\section{Opt Out}

A speaker who opts out the maxims shows the unwillingness to cooperate. $\mathrm{He} / \mathrm{she}$ wants to be looked uncooperative. Sometimes he/she cannot reply in the way expected because of legal or ethnical reasons (Cutting, 2002: 41). The example of opting out the maxims is when a police officer refuses to release the name of an accident victim until the relatives have been informed by saying 'I am afraid I can't give you that information' or by using expression like 'no comment'.

\section{Violation}

Thomas in Cutting (2002: 40) states that a speaker who violates the maxims actually knows that the hearer does not know the truth and he/she will only understand the superficial meaning of the words. He/she intentionally generate a misleading implicature by providing insufficient information, saying something that is insincere, irrelevant, or ambiguous so that the hearer wrongly assumes that the speaker is cooperating. In line with Thomas, Black (2006: 24) says that maxim violation is a quiet act that has an intention to mislead the meaning. It is also known as lying.

\section{Infringement}

Thomas in Cutting (2002: 41) states that a speaker who infringes the maxims fails to observe the maxims because he/she has imperfect linguistics performance. It can happen if the speaker has an imperfect command of the language such as a child or a foreign learner when their performance is impaired 
such as nervous, drunkenness, or excitement, if they have a cognitive impairment, or if they are simply incapable of speaking clearly.

\section{Flouting}

Flouting maxims is the only way of breaking maxims which generates implicature. Cutting (2002: 37) states that a speaker who flouts maxims expects the hearers to appreciate the meaning implied but he/she appears not to follow the maxims. Moreover, Black (2006: 25) explains that a speaker who flouts maxims is actually aware of the Cooperative Principles and the maxims. In other words, it is not only about the maxims that are broken down but that the speaker chooses an indirect way to achieve the cooperation of the communication. The four types of maxim flouting are explained in the following points.

\section{Maxim of Quantity Flouting}

When flouting the maxim of quantity, the speaker seems to give too little or to much information than is required. It can be said that the information that is given is insufficient.

\section{Maxim of Quality Flouting}

According to Cutting (2002: 37), a speaker who flouts the maxim of quality commonly says something that obviously does not represent what he/she thinks. The other ways of flouting the maxim of quality is by using hyperbole, metaphor, and, irony. A speaker seems to flout the maxim of quality when he/she exaggerates his/her statement.

\section{Maxim of Relation Flouting}

According to Thomas (1995: 70), a statement is made to be irrelevant to the topic in maxim of relation flouting. Moreover, Cutting (2002: 39) says that the speaker who flouts the maxim of relation expects the hearers to be able to imagine what the utterance did not say and make the connection between his/her utterance and the preceding one.

\section{Maxim of Manner Flouting}

Those who flout the maxim of manner are being obscure and often trying to exclude a third party (Cutting, 2002: 39). 


\section{RESEARCH METHOD}

This research only focuses in analyzing maxim flouting that occurs in the Kungfu Panda Movie. To describe the four types of maxim flouting, Cooperative Principles theory proposed by Grice is used. To identify the strategies of maxim flouting, Cutting's theory of strategies of maxim flouting is used.

This research used qualitative descriptive method, as stated by Ratna (2006:53) "qualitative descriptive method is done by describing facts which followed by analysis". The method describes the facts in the data then analyzes those aspects to reach the objectives of the research. The data source are taken from Kungfu Panda script by Jonathan Aibed \& Alan Berger and the secondary data are taken from the books, article, internet which are related to the focus of the research.

The data analysis was conducted by categorizing the data into the types and strategies of maxim flouting, analyzing the pursued data, checking the accuracy of the data, and then drawing the conclusions

\section{RESEARCH FINDING AND DISCUSSION}

\section{Maxim of Quantity Flouting}

When flouting the maxim of quantity, the speaker seems to give too little or to much information than is required. It can be said that the information that is given is insufficient (Cutting, 2002: 37).

\section{Giving Too Little Information Data 1:}

Po's dad: The dream. What were you dreaming about?

Po : What was I... eh, I was dreaming about uh... heh...Noodles.

In data 1 , Po seemed to be inconvenience to tell the truth about his dream. He was hesitant to tell it for the first and then he gave a very short answer. Po's dad at that time was expecting more information deal with Po's dream and it left him curious. The implicature that is generated from this dialog is Po was too scared to tell the truth of his dream, so he gave an answer that might make his dad happy by saying that he was dreaming about noodle. Based on the description about Po is fails to observe maxim quantity because he gave a very short answer. 


\section{Giving Too Much Information}

Data 9

Grateful Bunny : How can we repay you??

Warrior : There is no charge for awesomeness, or attractiveness.

In data 9, the grateful Bunny was glad to have been saved by the warrior. Yet, the warrior seemed to give response more than what have been expected. Thus, the warrior blatantly gave more information that the grateful Bunny needed, thereby generating the implicature that the warrior didn't need to be repaid as he just wanted to show his kung fu skill. Based on the description above the warrior fails to observe maxim quantity by providing too much information.

\section{Maxim of Quality Flouting}

According to Cutting (2002: 37), a speaker who flouts the maxim of quality commonly says something that obviously does not represent what he/she thinks. The other ways of flouting the maxim of quality is by using hyperbole, metaphor, and, irony. This type of flouting happens when one does not provide true information. He/she also has a lack of evidence to clarify the truth of his/her statement.

\section{Metaphor}

Metaphor happens when someone tries to make the listener believe that something is something else (Cutting, 2002: 38). It can be said that the speaker is comparing something with something else.

Data 13

Shifu

: We have to do something. We

can't just let him march on the

valley, and take his revenge!

$H e^{\prime} l l$, he'll--

Oogway : Your mind is like this water, my friend. When it is agitated, it becomes difficult to see. But if you allow it to settle, the answer becomes clear.

BRITISH, Jurnal Bahasa dan Sastra Inggris 
In data 13, master Shifu was being panic by the news that Tai Lung was escaped from prison, and then he asked for an advice to master Oogway. Yet, master Oogway replied in such a wise response. He says that "mind is like water when it is agitated, it becomes difficult to see but if you allow to settle the answer becomes clear". In this case Oogway expects Shifu as the hearer to get the implied meaning behind the utterance. Oogway tries to convey Shifu that he must calm to get the solution. By comparing his mind with water, it is considered that Oogway's utterance is an example of metaphor. Hence, this data is categorizes as metaphor because according to the Cutting's theory Metaphor happens when someone tries to make the listener believe that something is something else.

\section{Hyperbole}

According to Cutting (2002: 37), a speaker who flouts the maxim of quality can do it by using several ways. He/she may simply say something that obviously does not represent what they think. In addition, the speaker can flout the maxim by exaggerating his/her statement as in hyperbole.

Data 14:

$$
\begin{array}{ll}
\text { Po } & \text { : Dad Dad Dad, it } \\
\text { was just a dream. Po's dad } & \text { : No, it was the } \\
& \text { dream. We are noodle folk. } \\
& \text { Broth runs through our veins. }
\end{array}
$$

In data 14, Po said to his dad that the dream he had was just an ordinary dream. But, his dad argued that it was the dream, the sign that Po was ready to be entrusted with the secret ingredients soup. By saying "broth runs through our veins" He exaggerated to convince Po that broth runs through their blood, in which there was no evidence to explain it.

\section{Irony}

Cutting (2002: 38) states that by using irony, a speaker expresses a positive sentiment but implies a negative one. 
Data 16:

Viper $\quad$ : I don't understand what

Master Oogway was

thinking. The gonna get

himself killed.

Crane $\quad$ : He is so mighty! The

Dragon Warrior fell out of the sky on a ball of fire.

Mantis : When he walks, the very ground shakes!

In data 16, Viper was curious why the Panda was chosen as a dragon warrior. Meanwhile, Crane and Mantis were saying conversely by gave compliment to Panda. They said "He is so mighty" and "When he walks, the very ground shakes". At first it is expresses as a positive sentiment but actually implies a negative one. Hence, it is categorized as irony because according to the Cutting's theory that irony is when speaker expresses a positive sentiment but implies a negative one.

\section{Maxim of Relation}

To flout the maxim of relation, the speaker can be being irrelevant in responding to the previous topic talked before (Leech,1983:94). However, behind the irrelevant response, there are intended meanings which mean that the one who is being irrelevant flout the maxim of relation.

Data 17:

Po's dad : Oh, because it was a stupid dream. Can you imagine, me making tofu? No. We all have our place in this world. Mine is here. And yours is-

Po : I know. Is here.

Po's dad : No, it's at tables two, five, seven, and twelve.

In data 17, Po and his dad were having a conversation about the dream. Then, Po's dad said that Po's place was at tables two, five, seven and twelve. The implied meaning was that Po's dad wanted his son to help him serving the

BRITISH, Jurnal Bahasa dan Sastra Inggris 
costumers. This was clearly irrelevant with the previous topic they have discussed before.

\section{Maxim of Manner}

Those who flout the maxim of manner are being obscure and often trying to exclude a third party (Cutting, 2002: 39).

Data 25:

Shifu: Well done, students... if you were trying to disappoint me.

In data 25, they were having practice at that time, and master Shifu seemed to be disappointed. Yet, he praised his students first. He could simply say "I disappointed with you guys" instead of using satire. It indicated that master Shifu was very disappointed.

\section{CONCLUSION AND SUGGESTION}

Based on the explanation above, It can be concluded that all the main characters in the movie flouting all types of maxim. There are four types of maxim flouting. They are maxim of quantity, maxim of quality, maxim of manner, and maxim of relation flouting. The maxim of quantity flouting becomes the main type of maxim flouting which is performed by the main characters.

They have tendency to flout this maxim to make the information given to the listener clearer. It is done by giving too little information rather than giving much one. Meanwhile, maxim of quality and maxim of manner flouting rarely occurs in the movie because the characters are assertive kind of persons. They avoid giving unclear information which leads the understanding of the hearer.

\section{REFERENCES}

Bach Kent. 1999. The Myth of Conventional Implicature, Linguistics and Philosophy, 22,pp. 327-366

Black, E. 2006. Pragmatic Stylistics. Edinburgh: Edinburgh University Press.

Brown, G. and Yule, G. 1983. Discourse Analysis. Cambridge: Cambridge University Press. 
Cutting, j. 2002. Pragmatic and Discourse: a Resource Book for Students. New York: Routledge.

Cruse. 2006. A Glossary of Semantics and Pragmatics. Edinburgh: Edinburgh University Press.

Denscombe, M. 2007. The Good Research Guide for Small-Scale Social Research Projects ( $3^{\text {rd }}$ Edition). Berkshire: Open University Press

Djajasudarma, Fatimah. 1994. Wacana: Pemahaman dan Hubungan Antarunsur. Bandung; Freko

Grice, H.P. 2004. Conversational Implicature; Cooperative Principle.

Grundy, Peter. 2000. Doing Pragmatics. Oxford: Oxford University Press.

Hasan, A. D. 2014. A pragmatic Analysis of Maxim Flouting Performed by the Main Character in Philomena Movie.

Kusuma, J. A. 2012 A Socio-Pragmatic Analysis of the Flouting of Cooperative Principle Maxim Done by the Main Character in Cinderella man. Undergraduate Thesis. Yogyakarta State University.

Leech, G. N. 1983. Principle in Pragmatics. New York: Longman Group

Levinson, SC. 1983 Pragmatics. Cambridge: Cambridge University Press.

Maroon. 2016. Linguistics; Pengertian Linguistics Menurut Para Ahli

Monica Crabtree and Joyce Power. 1994. Material for an Introduction to language. Department of Linguistics: Ohio State University

McManis. 1988. The Study of the Contribution of Context to meaning. Pp. 197

Paltridge Brian. 2006. Discourses Analysis: An Introduction. New York: Continum

Parret. 1983. Aspect of a Cognitive- pragmatic Theory of Language, pp. 89.

Perin, Daniel and Griffler Brutt. 2012. Interational; Journal of Applied

Linguistics. Retrivied.

Raja T. Nasr. 1984. The Definition and Branches of Linguistics

BRITISH, Jurnal Bahasa dan Sastra Inggris 
Ratna, Nyoman Kuta. 2006. Teori, metodedan teknik penelitian sastra. Yogyakarta: Pustaka Pelajar

Thomas, J. 1995. Meaning in Interaction; an Introduction to Pragmatics. New York: Routledge

Vanderstoep, S. W. and Johnston, D. D. 2009. Research Methods for Everyday Life: Blending Qualitative and Quantitative Approaches. San Francisco: Jossey-Bass

Wierzbicka. 1991. Cross-cultural Pragmatics; The Semantics of Human Interaction

Yule, G. 1996. Pragmatics. Oxford: Oxford University Press. 
BRITISH, Jurnal Bahasa dan Sastra Inggris

Volume 08. No. 1 Juni 2019 
BRITISH, Jurnal Bahasa dan Sastra Inggris

Volume 08. No. 1 Juni 2019 